\title{
INCLUSION OF PROTECTED FAT IN DIETS ON THE MILK PRODUCTION AND COMPOSITION OF SAANEN GOATS
}

\author{
Inclusão de gordura protegida nas dietas sobre a \\ produção e composição do leite de cabras Saanen
}

\author{
Bruna Susan de Labio Molina ${ }^{1}$, Claudete Regina Alcalde ${ }^{2}$, Bruna Hygino², \\ Sérgio Mangano de Almeida Santos ${ }^{2}$, Ludmila Couto Gomes ${ }^{2}$, Geraldo Tadeu dos Santos ${ }^{2}$
}

\begin{abstract}
According on the fat source included in the diets for goats, the milk production can be increased and milk fatty acid composition can be improved. This study was conducted to evaluate the inclusion of protected fat (CSFA - calcium salts of fatty acids $)$ in the diets of lactating Saanen goats on milk production and composition. Five Saanen goats $(63.23 \pm 9.08 \mathrm{~kg}$ body weight and $105 \pm 3$ days of lactation) were distributed in a Latin square design $(5 \times 5)$ with five diets: control (without the addition of CSFA) and the other diets with: $6.25,12.50,18.75$ and $25.0 \mathrm{~g}$ CSFA per kg of dry matter (g/kg DM), respectively. Dry matter intake (DMI) and milk production (MP) were evaluated. Milk samples were collected to determine milk composition and fatty acid profile. Feed efficiency (FE) was estimated. The supplementation CSFA up to $25 \mathrm{~g} / \mathrm{kg}$ DM did not influence the DMI, MP and FE. Milk components production ( $\mathrm{g} / \mathrm{d}$ ) was not influenced by the inclusion of CSFA in the diet; however, there was a linear reduction of $0.87 \mathrm{~g}$ protein per $\mathrm{kg}$ of milk for each $1 \%$ CSFA included in the diet. The concentration of linolenic acid (18:3n-3) in milk was improved with a maximum point of $24 \mathrm{~g}$ CSFA per $\mathrm{kg}$ DM. CSFA can be included in the diets of lactating Saanen goats up to $25 \mathrm{~g} /$ $\mathrm{kg}$ DM with no interference on DMI and MP.
\end{abstract}

Index terms: Fatty acids; goat milk; Lactoplus ${ }^{\mathbb{B}}$; lipids; omega-3.

\section{RESUMO}

De acordo com a fonte de gordura incluída na dieta de cabras, a produção de leite pode ser aumentada e a composição de ácidos graxos do leite pode ser melhorada. Este estudo foi conduzido para avaliar a inclusão de gordura protegida (SCAG - sais de cálcio de ácidos graxos) nas dietas de cabras Saanen lactantes, sobre a produção e composição do leite. Cinco cabras Saanen (63,23 $\pm 9,08 \mathrm{~kg}$ de peso corporal e $105 \pm 3$ dias de lactação) foram distribuídas em delineamento quadrado Latino $(5 \times 5)$ em cinco dietas: controle (sem adição de SCAG) e os demais, dietas com: 6,25; 12,50; 18,75 e 25 g de SCAG por kg de matéria seca (g/kg MS), respectivamente. A ingestão de matéria seca (IMS) e a produção de leite (PL) foram avaliadas. Amostras de leite foram coletadas para determinar a composição e o perfil de ácidos graxos. A eficiência alimentar (EA) foi estimada. A suplementação de SCAG em até $25 \mathrm{~g} / \mathrm{kg}$ MS não influencia a IMS, PL e a EA. A produção de componentes do leite $(\mathrm{g} / \mathrm{d})$ não foi influenciada pela inclusão de SCAG na dieta, no entanto, houve redução linear de $0,87 \mathrm{~g}$ de proteína por $\mathrm{kg}$ de leite para cada $1 \%$ de inclusão de SCAG na dieta. A concentração de ácido linolênico (18:3n-3) no leite aumentou com o ponto de máxima de 24 g de SCAG por kg de MS. A gordura protegida pode ser incluída na dieta de cabras Saanen em lactação, em até $25 \mathrm{~g} / \mathrm{kg}$ MS sem interferir na IMS e PL.

Termos para indexação: Ácidos graxos; Lactoplus ${ }^{\circledR}$; leite de cabras; lipídios; ômega-3.

\section{INTRODUCTION}

Goat milk in Brazil is mainly consumed as an alternative feed for people that present with an allergy to milk from cows because it has a low $\alpha \mathrm{S} 1$-casein content (Greppi; Roncada; Fortin, 2008; Tomotake et al., 2006). Furthermore, the milk from goats contains fatty acids that are essential for human health, and small globules of fat when compared to the milk from cows (Attaie; Richter, 2000) what check a better digestibility for goat milk. The use of goat milk as a functional feed indicates a need for the specialization of the production chain as well as an improvement in the management of sanitation, reproduction, milking, and feed.

Generally, lipid supplements are added to the diets of lactating females to increase energy density; however, this also contributes to other purposes such as improving fat-soluble vitamin absorption, supplying important fatty acids for tissue membranes, acting as a precursor of metabolism regulation, increasing the efficiency of fat deposition, and improving milk synthesis (Palmquist; Mattos, 2011).

Protected fat is one of the supplements that is available in the market and is an ion complex of calcium with long chain fatty acids whose raw material

\footnotetext{
${ }^{1}$ Universidade Estadual de Maringá/UEM - Avenida Colombo - 5790 - 87020-900 - Maringá - PR - Brasil - brunamolina_@hotmail.com

2Universidade Estadual de Maringá/UEM - Departamento de Zootecnia - Maringá - PR - Brasil

Received in february 17, 2014 and approved in july 22, 2014
}

Ciênc. Agrotec., Lavras, v.39, n.2, p.164-172, mar./abr., 2015 
can be soybean oil or palm oil according to the commercial product. Protected fat is also called inert because it remains intact from the action of the rumen microorganisms without interfering in the fermentation process (Sirohi; Walli; Mohanta, 2010). Once the calcium ions are dissociated in the acidic conditions of the abomasum, the lipids become available for digestion and absorption directly from the intestine (Silva et al., 2007).

The dry matter intake can be reduced when a large percentage of protected fat is provided for goats (Sanz Sampelayo et al., 2002a); however, the efficient lipid digestion can increase milk production (Titi, 2011). Protected fat also allows for the increase of polyunsaturated fatty acid concentrations (Sanz Sampelayo et al., 2002b), which is a strategy to improve milk composition.

This study was conducted to evaluate the inclusion of calcium salts of fatty acids in diets on the dry matter intake, feed efficiency, milk production and composition, and concentration of fatty acids of milk from Saanen goats.

\section{MATERIAL AND METHODS}

The experiment was conducted at the Iguatemi Experimental Farm of the Universidade Estadual de Maringá, southern Brazil. Five multiparous Saanen goats (63.23 $\pm 9.08 \mathrm{~kg}$ body weight and $105 \pm 3$ days lactation) selected according to milk production in relation to body weight were distributed in a Latin square design $(5 \times 5)$ with five diets: control (without the addition of CSFA calcium salts of fatty acids) and the other diets with: 6.25 , $12.50,18.75$ and $25.0 \mathrm{~g}$ CSFA per $\mathrm{kg}$ dry matter $(\mathrm{g} / \mathrm{kg}$ DM), respectively.

The ingredients that were utilized to prepare the diets were ground corn, soybean meal, CSFA (calcium salts of fatty acids - Lactoplus ${ }^{\circledR}$ containing $1,760 \mathrm{~g} / \mathrm{kg}$ total digestible nutrients, $820 \mathrm{~g} / \mathrm{kg}$ ether extract, $100 \mathrm{~g} /$ $\mathrm{kg}$ calcium, $260 \mathrm{~g} / \mathrm{kg}$ oleic acid, and $420 \mathrm{~g} / \mathrm{kg}$ linoleic acid), and mineral supplement ${ }^{\mathbb{B}}$. The oat hay $(920 \mathrm{~g} / \mathrm{kg}$ dry matter, $78 \mathrm{~g} / \mathrm{kg}$ crude protein and $698 \mathrm{~g} / \mathrm{kg}$ neutral detergent fiber) was uzed at a proportion of $570 \mathrm{~g} / \mathrm{kg} \mathrm{DM}$ (Table 1). The diets were adjusted to provide $700 \mathrm{~g}$ total digestible nutrients and $155 \mathrm{~g}$ crude protein per kg dry matter, respectively, according to the NRC (2007).

Table 1: Chemical composition of the experimental diets.

\begin{tabular}{|c|c|c|c|c|c|}
\hline \multirow[t]{2}{*}{ Item (g/kg DM) } & \multicolumn{5}{|c|}{$\begin{array}{c}\text { Diets } \\
\text { (g CSFA } / \mathrm{kg} \mathrm{DM})\end{array}$} \\
\hline & 0 & 6.25 & 12.50 & 18.75 & 25.0 \\
\hline Oat hay & 570.00 & 570.00 & 570.00 & 570.00 & 570.00 \\
\hline Soybean meal & 187.85 & 185.12 & 182.39 & 179.66 & 176.93 \\
\hline Ground corn & 232.40 & 229.02 & 225.64 & 222.27 & 218.89 \\
\hline Lactoplus $^{\circledR 1}$ & - & 6.25 & 12.50 & 18.75 & 25.00 \\
\hline Mineral supplement ${ }^{\mathbb{} 2}$ & 9.75 & 9.61 & 9.47 & 9.32 & 9.18 \\
\hline Dry matter ${ }^{3}$ & 908.63 & 909.14 & 909.64 & 910.14 & 910.64 \\
\hline Organic matter & 940.36 & 939.45 & 938.55 & 937.65 & 936.74 \\
\hline Ash & 59.64 & 60.55 & 61.45 & 62.35 & 63.26 \\
\hline Crude protein & 161.83 & 160.13 & 158.43 & 156.73 & 155.02 \\
\hline Ether extract ${ }^{4}$ & 20.38 & 25.35 & 30.30 & 35.26 & 40.22 \\
\hline Neutral detergent fiber & 460.24 & 459.33 & 458.43 & 457.52 & 456.61 \\
\hline Non-fiber carbohydrates & 297.90 & 294.65 & 291.40 & 288.14 & 284.89 \\
\hline Total carbohydrates & 758.14 & 753.98 & 749.82 & 745.66 & 741.50 \\
\hline Digestible energy $^{5}$ & 2.82 & 2.75 & 2.71 & 2.86 & 2.87 \\
\hline
\end{tabular}

${ }^{1}$ Calcium salts of fatty acids. ${ }^{2}$ Commercial product. Composition (per kg product): $240 \mathrm{~g} \mathrm{Ca} ; 71 \mathrm{~g} \mathrm{P} ; 710 \mathrm{mg} \mathrm{F}$ (Max); $20 \mathrm{~g} \mathrm{Mg}$ $\mathrm{K} ; 28,20 \mathrm{~g} ; 20 \mathrm{~g} \mathrm{~S} ; 2.500 \mathrm{mg} \mathrm{Fe} ; 400 \mathrm{mg} \mathrm{Cu} ; 1.350 \mathrm{mg} \mathrm{Mn} ; 1.700 \mathrm{mg} \mathrm{Zn;} 30 \mathrm{mg} \mathrm{Co} ; 40 \mathrm{mg} \mathrm{I} ; 15 \mathrm{mg} \mathrm{Se} ; 10 \mathrm{mg} \mathrm{Cr}-; 135.000 \mathrm{UI}$ vitamin A; 68.000 UI vitamin D3; 450 UI vitamin E; ${ }^{3} \mathrm{~g} / \mathrm{kg}$ natural matter; ${ }^{4}$ Obtained from the result of the chemical composition of foods (oat hay, ground corn and soybean meal) and the composition of Lactoplus ${ }^{\circledR}$ (Dalquim Chemical Industry Ltd.); ${ }^{5} \mathrm{Obtained}$ from the equation: DE $(\mathrm{Mcal} / \mathrm{kg} \mathrm{DM})=0.04409 \times \mathrm{TDN}(\%)(\mathrm{NRC}, 2001)$. 
The feed samples were processed in a Willey type mill using a $1 \mathrm{~mm}$ screen and stored in plastic bottle for further analyses.

Dry matter (DM), crude protein $(\mathrm{CP})$, ash, and ether extract (EE) were analyzed according to AOAC as described by Silva and Queiroz (2002), and neutral detergent fiber was analyzed according to Van Soest, Robertson and Lewis (1991) as adapted by Souza et al. (1999). Organic matter was estimated by calculating the difference between dry matter and ash contents.

The total carbohydrates (TC) and total digestible nutrients (TDN) were estimated according to the equation described by Sniffen et al. (1992): TC $(\mathrm{g} / \mathrm{kg} \mathrm{DM})=1000$ $-(\mathrm{CP}+\mathrm{EE}+\mathrm{ash})$ and $\mathrm{TDN}=\mathrm{CPd}+(2.25 \times \mathrm{EEd})+\mathrm{TCd}$, where $\mathrm{CPd}=$ digestible crude protein, $\mathrm{EEd}=$ digestible ether extract, and $\mathrm{TCd}=$ digestible total carbohydrates. The values for non-fiber carbohydrates (NFC) were estimated according to the equation proposed by Van Soest, Robertson and Lewis (1991): NFC (g/kg DM) = $1000-(\mathrm{NDF}+\mathrm{CP}+\mathrm{EE}+$ ash $)$. The values for crude energy were determined via adiabatic calorimetric bomb (PARR Instruments Co. AC720, USA). Digestible energy (DE) of diets was calculated by the following equation from NRC (2001): $\mathrm{DE}(\mathrm{Mcal} / \mathrm{kg})=0.04409 \times \mathrm{TDN}(\%)$.

Each experimental period was composed of 21 days, with 15 days for the animals to adapt to the diets and six days of data collection (week of evaluation), thereby totaling 105 days of experiment. The goats were housed in individual pens with ad libitum water, and access to the solarium in the morning.

Body weight was recorded at the beginning of each experimental period after the morning milking and before the supply of the ration.

Goats were fed at $9 \mathrm{~h}$ and $16 \mathrm{~h}$ and the orts were measured daily to determine the intake. Samples of orts were collected daily from 16 th to 21 th of the experimental periods.

The samples of orts were stored in a freezer, and at the end of the collections they were defrosted, dried in a forced oven for 72 hours at $55^{\circ} \mathrm{C}$, ground in a Willey type mill using a $1 \mathrm{~mm}$ screen, and analyzed for dry matter, according to the procedures previously described for feed samples, to determine the dry matter intake (DMI).

The goats were milked twice daily (7h30 and 15h30) followed by individual milk weighting. For each experimental period, individual milk samples were collected at the 16th day proportionally to milk production of the morning and afternoon milkings.

Milk production was corrected for $35 \mathrm{~g}$ fat per $\mathrm{kg}$ milk according to the Gravert (1987) equation: FCM (35 $\mathrm{g} / \mathrm{kg})=0.4337 \times \mathrm{MP}+16.218 \times \mathrm{FP}$, where $\mathrm{FCM}=$ fat corrected milk, $\mathrm{MP}=$ milk production $(\mathrm{kg} / \mathrm{d})$, and $\mathrm{FP}=$ fat production $(\mathrm{kg} / \mathrm{d})$.

For chemical composition determination, milk samples were stored in plastic bottles containing the preservative Bronopol ${ }^{\circledR}$ (2-bromo-2-nitropropane-1,3-diol) and analyzed for fat, protein, lactose, and total solids by infrared spectrophotometry (Bentley model 2000; Bentley Instrument Inc., Chaska, MN). Also, the somatic cell count (SCC) was performed by using an electronic counter (Somacount 500, Chaska, MN).

Another two milk samples were collected in plastic bottles without addition the preservative and frozen, one for milk fatty acid and the other one for urea analyzes.

Milk fat was obtained by centrifugation according to the methodology described by Murphy, Connolly and Mcneill (1995), and was esterified according to the method 5509 of ISO (1978) in a solution of $\mathrm{KOH} /$ methanol and n-heptane. Fatty acid methyl esters were quantified by gas chromatography (Trace GC Ultra, Thermo Scientific, USA) equipped with a flame ionization detector at $240^{\circ} \mathrm{C}$ and a capillary column of fused silica (100 m length, 0.25 $\mathrm{mm}$ internal diameter, and $0.20 \mu \mathrm{m}$, Restek 2560).

Fatty acids were quantified (g/100g lipids) by comparison with the retention time of the methyl esters from fatty acids of the sample standards tricosanoic acid methyl ester (23:0) (Sigma Aldrich ${ }^{\circledR}$, Brazil). The column parameters were as follows: initial column temperature of $65^{\circ} \mathrm{C}$ was maintained for $8 \mathrm{~min}$; the temperature was then programmed at $50^{\circ} \mathrm{C} / \mathrm{min}$ to $170^{\circ} \mathrm{C}$; this temperature was maintained for $40 \mathrm{~min}$ and then increased $50^{\circ} \mathrm{C} / \mathrm{min}$ to $240^{\circ} \mathrm{C}$ and remained for $28.5 \mathrm{~min}$. Injector and detector temperatures were 220 and $245^{\circ} \mathrm{C}$, respectively. The gas flow was $1.5 \mathrm{ml} / \mathrm{min}$ for hydrogen (carrier gas), $30 \mathrm{ml} /$ min for $\mathrm{N} 2$ (auxiliary gas), $35 \mathrm{ml} / \mathrm{min}$ for $\mathrm{H} 2$ and $350 \mathrm{ml} /$ min for compressed air. With a microliter syringe, $2 \mu \mathrm{L}$ of samples were inject with a split ratio of $1: 100$. Fatty acid peaks were identified by comparison of the retention times of pure methyl ester standards (Sigma Aldrich ${ }^{\circledR}$, Brazil).

At the 21th day of the experimental periods blood samples were collected from the goats after the morning milking (before feeding) by jugular vein puncture using $5 \mathrm{~mL}$ vials. The samples were centrifuged $(3,000 \mathrm{rpm}$ for 15 minutes) to obtain the serum, which was stored in eppendorfs and analyzed by a biochemical semiautomatic analyzer using an enzyme-colorimetric kit (Gold Analisa Diagnostica $\operatorname{Ltda}^{\circledR}$ ) for urea concentration.

Feed efficiency was calculated by determining the ratio between the average milk production and the average dry matter intake, in $\mathrm{kg} / \mathrm{kg}$. 
The data were submitted to variance analysis via polynomial regression $(\mathrm{P}<0.05)$ by using the SAEG (Genetic and Statistical Analyses System - UFV version 7.1) program.

\section{RESULTS AND DISCUSSION}

Dry matter intake (DMI), milk production (MP), and milk production corrected for $35 \mathrm{~g}$ of fat per $\mathrm{kg}$ of milk $\left(\mathrm{FCM}_{3.5 \%}\right)$ were not influenced $(\mathrm{P}>0.05)$ by the inclusion of CSFA in the diets, and had average values of 2.04, 2.07 and $1.9 \mathrm{~kg} / \mathrm{d}$, respectively (Table 2).

DMI determines the nutrient supply needed to meet the requirements for maintenance and production (Carvalho et al., 2006); therefore, among the several factors that determine milk production, maximization of the intake is one of the decisive factors that should be taken into consideration. The result observed for DMI indicates that although the protected fat presents with the characteristic odor of soap (fatty acid calcium soap), its inclusion in the diet did not restrict DMI, thereby leading to a good level of acceptance of the product without influencing the flavor for goats.

The use of CSFA for lactating goats in diets in proportions from 30 to $90 \mathrm{~g} / \mathrm{kg}$ DM does not seems to influence the intake (Silva et al., 2007; Teh et al., 1994). However, when CSFA fat is included in greater proportions in the diet, the intake can be influenced. In a study with inclusion levels of 0,90 and $120 \mathrm{~g}$ protected fat per $\mathrm{kg}$ of dry matter in the diets of goats, Sanz Sampelayo et al. (2002a) reported that there was a refusal in the intake of concentrate due to the reduced palatability of diets with protected fat.

There was no influence $(\mathrm{P}>0.05)$ of the inclusion of CSFA in diets on milk production. Sanz Sampelayo et al. (2002b) supplemented lactating goats with higher amounts of protected fat $(0,90$ and $120 \mathrm{~g} / \mathrm{kg} \mathrm{DM})$ and did not observe changes in the milk production. The authors justified this due to the similar metabolizable energy intake results among the evaluated diets, since the energy of the diet is an important factor that limits milk production.

Feed efficiency (FE), and feed efficiency considering the milk production corrected (FEc) with averages of 1.01 and 0.95 , respectively, were not influenced due the results obtained for milk production and dry matter intake. In a study conducted where lactating Saanen goats received different roughage:concentrate proportions, Zambom et al. (2005) observed a value of 1.05 for the FE, when the goats were provided with $60 \%$ oat hay, a value that is close to the obtained average.

Gomes et al. (2012) reported a FE of 1.63, while Mendes et al. (2010) observed an average FEc of 1.26 for Saanen and Brown-Alpine goats, respectively, receiving corn silage. When roughage sources as the corn silage, that present a lower cell wall content and grains, are added to the ruminant diets, better conditions of rumen fermentation are promoted, which contributes to greater feed efficiency values, when compared to those results obtained with dry roughage such as the used oat hay.

The production of fat, protein, lactose, and total solids of the milk $(\mathrm{g} / \mathrm{d})$ were not influenced $(\mathrm{P}>0.05)$ by the inclusion of CSFA in diets, although with regards to the concentration of these components, there was a negative linear effect $(\mathrm{P}<0.05)$ on protein content, with a decrease of $0.87 \mathrm{~g} / \mathrm{kg}$ milk for each $1 \%$ CSFA included in the diet (Table 3).

One of the possible explanations for the linear reduction in the observed concentrations of milk protein, according to the inclusion of protected fat in diets, can be related to the reduction in rumen fermentable organic matter; this effect may be caused by the replacement of

Table 2: Dry matter intake (DMI), milk production (MP), fat corrected milk 3.5\% $\left(\mathrm{FCM}_{3.5 \%}\right)$, feed efficiency (FE) of Saanen goats receiving diets with protected fat.

\begin{tabular}{ccccccccc}
\hline \multirow{2}{*}{ Item } & \multicolumn{9}{c}{ Diets } & \multicolumn{2}{c}{ CV } & \multicolumn{2}{c}{$P$-values } \\
\cline { 2 - 5 } & 0 & 6.25 & 12.50 & 18.75 & 25.0 & & linear & quadratic \\
\hline DMI $^{1}$ & 2.00 & 2.02 & 2.15 & 2.03 & 2.01 & 6.08 & $>0.05$ & 0.13 \\
$\mathrm{MP}^{1}$ & 2.02 & 2.06 & 2.14 & 2.07 & 2.09 & 6.28 & $>0.05$ & $>0.05$ \\
$\mathrm{FCM}_{3.5 \%}{ }^{1}$ & 1.87 & 1.96 & 2.00 & 1.95 & 1.98 & 8.37 & $>0.05$ & $>0.05$ \\
$\mathrm{FE}^{2}$ & 1.01 & 1.01 & 0.99 & 1.02 & 1.03 & 5.32 & $>0.05$ & $>0.05$ \\
$\mathrm{FEc}^{3}$ & 0.93 & 0.96 & 0.93 & 0.96 & 0.97 & 6.92 & $>0.05$ & $>0.05$ \\
\hline
\end{tabular}

${ }^{\mathrm{kgg} / \text { day; }{ }^{2} \mathrm{~kg} \text { milk/kg DMI; }{ }^{3} \mathrm{~kg} \mathrm{FCM}}{ }_{3.5 \%} / \mathrm{kg}$ DMI; CV (coefficient of variation (\%)). 
fermentable starch from corn by a fat with high intestinal digestibility, which decreases the available energy for rumen fermentation (Geron et al., 2011). This process reduces microbial protein synthesis in the rumen, which is the main source of metabolizable protein that is needed for milk protein synthesis (Santos; Pedroso, 2011).

Moreover, obtaining an optimal proportion between energy and protein is important, as it can be used to obtain better results for microbial production, better use of nutrients from the diet, and can consequently improve performance (Rodrigues et al., 2007).

The number of somatic cells was not influenced with the addition of CSFA in the diets, and the obtained average $\left(3.32 \log _{10}\right.$ cells $\left./ \mathrm{mL} \times 1000\right)$ is close to values of $3.26 \log _{10}$ cells $/ \mathrm{mL} \times 1000$ reported by Ribeiro et al. (2008) in goats. However, Gomes et al. (2012) observed values of 2.84 and $3.07 \log _{10}$ cells $/ \mathrm{mL} \times 1000$ in post peak periods and at the end of lactation, respectively, for multiparous Saanen goats. Although there is currently no legal limit of the number of somatic cell count for goat milk in Brazil (Brasil, 2000) the values observed are higher than the limit of $1,000,000$ cells $/ \mathrm{mL}\left(3.0 \log _{10}\right.$ cell $/ \mathrm{mL} \times$ 1000 ) established by Food and Drug Administration in the United States of America.

The inclusion of CSFA in diets of goats did not influence the concentrations of urea in the serum or in the milk ( $\mathrm{P}>0.05)$, thus indicating a satisfactory metabolic status; in other words, an adequate amount of nitrogen and energy was provided by the diets (Table 4).

Ribeiro et al. (2008), after providing alfalfa hay and corn silage as roughage sources to dairy goats, reported a blood urea concentration of 94.22 and $117.22 \mathrm{mg} / \mathrm{dL}$, respectively, but when the oat hay was the roughage source, the average corresponded to $74.22 \mathrm{mg} / \mathrm{dL}$ blood urea, a value that was close to the observed value (61.97 $\mathrm{mg} / \mathrm{dL})$.

Table 3: Milk production and composition of Saanen goats receiving diets with protected fat.

\begin{tabular}{|c|c|c|c|c|c|c|c|c|}
\hline \multirow[t]{2}{*}{ Item } & \multicolumn{5}{|c|}{ (g CSFA/kg DM) } & \multirow[t]{2}{*}{$\mathrm{CV}$} & \multicolumn{2}{|c|}{$P$-values } \\
\hline & 0 & 6.25 & 12.50 & 18.75 & 25.0 & & linear & quadratic \\
\hline \multicolumn{9}{|c|}{ Production $(g / d)$} \\
\hline Fat & 61.44 & 66.07 & 66.45 & 64.51 & 66.49 & 10.89 & $>0.05$ & $>0.05$ \\
\hline Protein & 60.29 & 57.30 & 59.83 & 57.20 & 56.39 & 8.06 & $>0.05$ & $>0.05$ \\
\hline Lactose & 81.30 & 83.59 & 87.30 & 84.40 & 85.32 & 5.80 & 0.23 & 0.28 \\
\hline Total solids & 219.04 & 222.86 & 230.56 & 222.41 & 224.79 & 7.09 & $>0.05$ & $>0.05$ \\
\hline \multicolumn{9}{|c|}{ Composition $(\mathrm{g} / \mathrm{kg})$} \\
\hline Fat & 30.26 & 31.62 & 30.74 & 30.64 & 31.26 & 6.79 & $>0.05$ & $>0.05$ \\
\hline Protein & 29.92 & 28.12 & 28.24 & 27.82 & 27.30 & 3.57 & $<0.01^{\mathrm{a}}$ & 0.26 \\
\hline Lactose & 40.44 & 40.78 & 40.98 & 40.84 & 41.06 & 1.71 & 0.26 & $>0.05$ \\
\hline Total solids & 108.58 & 108.30 & 107.92 & 107.20 & 107.62 & 1.75 & 0.28 & $>0.05$ \\
\hline $\mathrm{SCC}^{1}$ & 3.32 & 3.47 & 3.24 & 3.40 & 3.15 & 6.47 & 0.21 & 0.28 \\
\hline
\end{tabular}

Table 4: Urea concentrations in blood and milk of Saanen goats receiving diets with protected fat.

\begin{tabular}{ccccccccc}
\hline & \multicolumn{9}{c}{ Diets } \\
Item $(\mathrm{mg} / \mathrm{dL})$ & \multicolumn{9}{c}{$(\mathrm{g} \mathrm{CSFA} / \mathrm{kg} \mathrm{DM})$} & \multicolumn{2}{c}{$\mathrm{CV}$} & \multicolumn{2}{c}{$P$-values } \\
\hline & 0 & $6.25 \mathrm{w}$ & 12.50 & 18.75 & 25.0 & & linear & quadratic \\
\hline Blood & 64.61 & 63.08 & 60.36 & 61.68 & 60.10 & 8.45 & 0.18 & $>0.05$ \\
Milk & 62.79 & 58.54 & 57.29 & 58.97 & 58.88 & 6.94 & 0.23 & 0.13 \\
\hline
\end{tabular}

$\mathrm{CV}$ [coefficient of variation (\%)]. 
The concentration of milk urea can be considered a good indicator of metabolism and protein intake for dairy animals, and can be utilized for dietary evaluation (Fernandes et al., 2008). However, the high positive linear correlation $(r=0.9288)$ that was observed between the results of urea in the milk and blood (Mouro et al., 2002) allows for the choice of one of these methods to evaluate protein animal metabolism.

According to Maia et al. (2010), changes in the blood urea concentration are related to the rumen ammonia content, which is transformed by rumen microorganisms to microbial protein, the main milk protein source. If the available energy for these processes in the rumen is insufficient, ammonia accumulation and an increase in the blood urea concentration can occur, which was not observed with the inclusion of protected fat in diets (Table 4).

The inclusion of CSFA in the diets did not influence $(\mathrm{P}>0.05)$ milk fat content; however, the concentration of fatty acids was modified. There was a linear reduction $(\mathrm{P}<0.05)$ in the concentration of stearic acid $(18: 0)$ and a quadratic effect $(\mathrm{P}<0.05)$ on the concentration of linolenic acid (18:3 n-3) (Table 5).

With regards to the degree of saturation of fatty acids identified in milk fat, the concentrations presented

Table 5: Fatty acids concentration (g/100g fatty acids) of fat milk of Saanen goats receiving protected fat in diets.

\begin{tabular}{|c|c|c|c|c|c|c|c|c|}
\hline \multirow[t]{2}{*}{ Item } & \multicolumn{5}{|c|}{ Diets } & \multirow[t]{2}{*}{$\mathrm{CV}$} & \multicolumn{2}{|c|}{$P$-values } \\
\hline & 0 & 6.25 & 12.50 & 18.75 & 25 & & linear & quadratic \\
\hline $4: 0$ & 2.63 & 2.43 & 2.55 & 2.47 & 2.51 & 5.27 & 0.32 & 0.21 \\
\hline $6: 0$ & 3.04 & 3.10 & 3.05 & 3.03 & 3.02 & 18.95 & $>0.05$ & $>0.05$ \\
\hline $8: 0$ & 3.72 & 3.68 & 3.66 & 3.59 & 3.70 & 6.40 & $>0.05$ & $>0.05$ \\
\hline $10: 0$ & 6.39 & 6.64 & 6.20 & 6.66 & 6.22 & 7.02 & $>0.05$ & $>0.05$ \\
\hline $12: 0$ & 4.52 & 4.43 & 4.46 & 4.38 & 4.46 & 6.12 & $>0.05$ & $>0.05$ \\
\hline $13: 0$ & 2.65 & 2.75 & 2.79 & 2.58 & 2.69 & 6.68 & $>0.05$ & $>0.05$ \\
\hline $14: 0$ & 8.57 & 8.33 & 8.18 & 8.28 & 8.25 & 4.40 & 0.20 & 0.29 \\
\hline $15: 0$ & 0.51 & 0.55 & 0.52 & 0.56 & 0.56 & 9.60 & 0.14 & $>0.05$ \\
\hline $16: 0$ & 17.25 & 17.85 & 18.77 & 16.83 & 18.64 & 7.84 & $>0.05$ & $>0.05$ \\
\hline $17: 0$ & 0.43 & 0.38 & 0.51 & 0.31 & 0.43 & 27.64 & $>0.05$ & $>0.05$ \\
\hline $18: 0$ & 12.77 & 12.14 & 12.52 & 11.98 & 11.97 & 3.88 & $0.03^{\mathrm{a}}$ & $>0.05$ \\
\hline $18: 1 n-9$ & 23.53 & 23.90 & 22.85 & 25.17 & 23.21 & 6.74 & $>0.05$ & $>0.05$ \\
\hline $18: 2 n-6$ & 6.97 & 7.70 & 7.08 & 6.74 & 7.43 & 13.24 & $>0.05$ & $>0.05$ \\
\hline $18: 3 n-3$ & 0.21 & 0.22 & 0.23 & 0.22 & 0.21 & 9.75 & $>0.05$ & $0.04^{\mathrm{b}}$ \\
\hline $18: 2$ c-9 t-11 & 1.86 & 1.33 & 1.48 & 1.85 & 1.45 & 23.70 & $>0.05$ & $>0.05$ \\
\hline Others $^{2}$ & 4.95 & 4.57 & 5.15 & 5.35 & 5.25 & 15.56 & 0.24 & $>0.05$ \\
\hline SFA & 65.29 & 64.86 & 65.87 & 63.79 & 65.21 & 2.34 & $>0.05$ & $>0.05$ \\
\hline MUFA & 24.99 & 25.26 & 24.41 & 26.69 & 24.75 & 6.39 & $>0.05$ & $>0.05$ \\
\hline PUFA & 9.72 & 9.88 & 9.72 & 9.51 & 10.04 & 7.31 & $>0.05$ & $>0.05$ \\
\hline PUFA/SFA & 0.15 & 0.15 & 0.15 & 0.15 & 0.15 & 7.80 & $>0.05$ & $>0.05$ \\
\hline n-3 & 0.27 & 0.30 & 0.37 & 0.33 & 0.36 & 23.39 & 0.09 & $>0.05$ \\
\hline $\mathrm{n}-6$ & 7.32 & 8.05 & 7.50 & 7.12 & 7.80 & 12.17 & $>0.05$ & $>0.05$ \\
\hline$n-6: n-3$ & 29.89 & 31.61 & 24.72 & 23.67 & 28.03 & 32.48 & $>0.05$ & $>0.05$ \\
\hline
\end{tabular}

${ }^{1} \mathrm{~ns}(\mathrm{P}>0,05) ;{ }^{2}$ others fatty acids; $\mathrm{R}^{2}$ (coefficient of determination); $\mathrm{CV}$ [coefficient of variation (\%)]; SFA = saturated fatty acids; MUFA = monounsaturated fatty acids; PUFA = polyunsaturated fatty acid; $n-3=$ Omega-3 fatty acids; $n-6=$ Omega- 6 fatty acids;

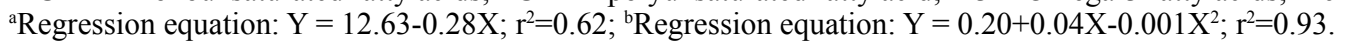


in decreasing order as follows: saturated $(65 \mathrm{~g} / 100 \mathrm{~g})>$ monounsaturated $(25.22 \mathrm{~g} / 100 \mathrm{~g})>$ polyunsaturated $(9.77$ $\mathrm{g} / 100 \mathrm{~g}$ ). These results were more interesting than those obtained by Queiroga et al. (2007) for goat milk; their average saturated, monounsaturated, and polyunsaturated acid values were $75.91,21.89$ and $2.19 \mathrm{~g} / 100 \mathrm{~g}$ fatty acids, respectively, due to the greater unsaturated fatty acid content.

Among the saturated fatty acids, those that are highlighted in goat milk are capric (10:0), myristic (14:0), palmitic (16:0), and stearic (18:0), which were observed in greater concentrations (Costa et al., 2008), and corresponded to the obtained values (Table 5).

The reduced concentration of stearic acid (18:0) is related to the activity of the $\Delta 9$ - desaturase enzyme in the mammary gland that catalyzes the insertion of a double bond in its molecule, converting C18:0 to oleic acid (18:1); however, a difference was not observed $(\mathrm{P}>0.05)$ in the concentration of oleic acid in the milk fat.

The quadratic effect $(\mathrm{P}<0.05)$ observed with the incorporation of linolenic acid (18:3 n-3) in the milk fat favored a concentration with a maximum point of $24 \mathrm{~g}$ CSFA per kg dry matter. Although, when Titi (2011) supplemented goats from the beginning until the intermediate phase of lactation, they reported an increase in the concentration of linolenic acid (18:3 n-3) with the supplementation of $50 \mathrm{~g}$ protected fat per kg dry matter.

When evaluating the effects of increasing levels of energy in the diets of goats with the addition of CSFA $(0,28.7,54.6$ and $80.5 \mathrm{~g} / \mathrm{kg} \mathrm{DM})$, Souza et al. (2014) observed that supplementation improved milk yield with higher levels of essential fatty acids omega-3 (n-3) and omega-6 (n-6).

Although a quadratic effect $(\mathrm{P}<0.05)$ was seen in the concentration of 18:3 n-3 (Table 5) the supplementation of CSFA did not increase the total concentration of omega- 3 fatty acids, and therefore, did not alter the omega-6/omega-3 ratio.

\section{CONCLUSION}

Calcium salts of fatty acids can be included in the diets of goats without interfering with intake and milk production, with improvement of the concentration of linolenic acid (18:3 n-3); nevertheless, the concentration of milk protein is reduced.

\section{ACKNOWLEDGMENTS}

The authors gratefully acknowledge the Associação Paranaense de Criadores de Bovinos da Raça Holandesa - APCBRH, Curitiba, PR, Brazil and Ms. Paula Adriana
Grande, UEM, PR, Brazil for assistance in the laboratory of milk analyses.

\section{REFERENCES}

ATTAIE R.; RICHTER R.L. Size distribution of fat globules in goat milk. Journal of Dairy Science. 83(5):940-944, 2000.

BRASIL, 2000. Instrução Normativa $\mathbf{n}^{0} 37$. Regulamento Técnico de Produção, Identidade e Qualidade do Leite de Cabra. Diário Oficial da União, Brasília.

CARVALHO, S. et al. Consumo de nutrientes, produção e composição do leite de cabras da raça Alpina alimentadas com dietas contendo diferentes teores de fibra. Revista Brasileira de Zootecnia. 35(3):11541161, 2006.

COSTA, R.G. et al. Características químicas e sensoriais do leite de cabras Moxotó alimentadas com silagem de maniçoba. Revista Brasileira de Zootecnia. 37(4):694702, 2008.

FERNANDES, M.F. et al. Características físicoquímicas e perfil lipídico do leite de cabras mestiças Moxotó alimentadas com dietas suplementadas com óleo de semente de algodão ou de girassol. Revista Brasileira de Zootecnia. 37(4):703-710, 2008.

GERON, L.J.V. et al. Inclusão do caroço de algodão em rações de alto concentrado constituído de coprodutos agroindustriais sobre o desempenho animal em tourinhos confinados. Archives of Veterinary Science. 16(3):14-24, 2011.

GOMES, L.C. et al. Performance of lactating goats fed diets containing inactive dry yeast. Revista Brasileira de Zootecnia. 41(10):2249-2254, 2012.

GRAVERT, H. O. Dairy Cattle Production. Nova York: Elsevier Science, 1987. 234p.

GREPPI, G.F.; RONCADA, P.; FORTIN, R. Protein components of goat's milk. In: CANNAS, A.; PULINA, G. (Eds.). Dairy Goats Feeding and Nutrition. Oxfordshire: CAB International, 2008, p.71-94. 
INTERNATIONAL ORGANIZATION FOR STANDARDIZATION - ISO. Animal and Vegetable Fats and Oils - Preparation of Methyl Esters of Fatty Acids. Geneva: Method ISO 5509, 1978. 24p.

MAIA, M.O. et al. Consumo, digestibilidade de nutrientes e parâmetros sanguíneos de cabras mestiças moxotó suplementadas com óleos de licuri ou mamona. Ciência Rural. 40(1):149-155, 2010.

MENDES, C.Q. et al. Substituição parcial do farelo de soja por ureia ou amireia na alimentação de cabras em lactação. Revista Brasileira de Zootecnia. 39(8):18181824, 2010.

MOURO, G.F. et al. Substituição do milho pela farinha de mandioca de varredura em dietas de cabras em lactação: fermentação ruminal e concentrações de uréia plasmática e no leite. Revista Brasileira de Zootecnia. 31(4):1840-1848, 2002.

MURPHY, J.J.; CONNOLLY, J.F.; McNEILL, G.P. Effects on milk fat composition and cow performance of feeding concentrates containing full fat rapeseed and maize distillers grains on grasssilage based diets. Livestock Production Science. 44(1):1-11, 1995.

NATIONAL RESEARCH COUNCIL - NRC. Nutrient requirements of dairy cattle. Washington, D.C.:

National Academy of Science. 2001. 381p.

NATIONAL RESEARCH COUNCIL - NRC. Nutrient Requirements of Small Ruminants, Washington, D.C.: National Academy Press. 2007. 362p.

PALMQUIST, D.L.; MATTOS, W.R.S. Metabolismo de lipídeos. In: BERCHIELLI, T.T.; PIRES, A.V.; OLIVEIRA, S.G. et al. Nutrição de Ruminantes. 2.ed. Jaboticabal: Funep, 2011. p.299-322.

QUEIROGA, R.C.R.E. et al. Influência do manejo do rebanho, das condições higiênicas da ordenha e da fase de lactação na composição química do leite de cabras Saanen. Revista Brasileira de Zootecnia. 36(2):430437, 2007.

RIBEIRO, L.R. et al. Produção, composição do leite e constituintes sangüíneos de cabras alimentadas com diferentes volumosos. Arquivo Brasileiro de
Medicina Veterinária e Zootecnia, 60(6):15231530, 2008.

RODRIGUES, C.A.F. et al. Consumo, digestibilidade e produção de leite de cabras leiteiras alimentadas com dietas contendo diferentes níveis de proteína bruta e energia líquida. Revista Brasileira de Zootecnia. 36(5):1658-1665, 2007.

SANTOS, F.A.P.; PEDROSO, A.M. Metabolismo de proteínas. In: BERCHIELLI, T.T.; PIRES, A.V.; OLIVEIRA, S.G. Nutrição de Ruminantes. 2.ed. Jaboticabal: Funep, 2011. p.265-297.

SANZ SAMPELAYO, M.R. et al. Effects of concentrates with different contents of protected fat rich in PUFAs on the performance of lactating Granadina goats. 1. Feed intake, nutrient digestibility, $\mathrm{N}$ and energy utilization for milk production. Small Ruminant Research. 43(2):133-139, 2002a.

SANZ SAMPELAYO, M.R. et al. Effects of concentrates with different contents of protected fat rich in PUFAs on the performance of lactating Granadina goats. 2. Milk production and composition. Small Ruminant Research. 43(2):141-148, $2002 \mathrm{~b}$.

SILVA, D.J.; QUEIROZ, A.C. Análise de Alimentos: métodos químicos e biológicos. 5.ed. Viçosa: Imprensa Universitária, 2002. 235p.

SILVA, M.M.C. et al. Suplementação de lipídios em dietas para cabras em lactação: consumo e eficiência de utilização de nutrientes. Revista Brasileira de Zootecnia. 36(1):257-267, 2007.

SIROHI, S.K.; WALLI, T.K.; MOHANTA, R.K. Supplementation effect of bypass fat on production performance of lactating crossbred cows. Indian Journal of Animal Sciences. 80(8):733-736, 2010.

SNIFFEN, C.J. et al. A net carbohydrate and protein system for evaluating cattle diets: II. Carbohydrate and protein availability. Journal of Animal Science. 70(10):3562-3577, 1992.

SOUZA, G.B. et al. Método alternativo para a determinação de fibra em detergente neutro e detergente ácido. São Carlos: EMBRAPA CPPSE. Boletim de pesquisa n.04, 1999. 21p. 
SOUZA, R. et al. Effects of dietary energy levels using calcium salts of fatty acids on nutritive value of diets and milk quality in peripartum dairy goats. Ciência e Agrotecnologia. 38(3):286-294, 2014.

TEH, T.H. et al. Varying amounts of rumen-inert fat for high producing goats in early lactation. Journal of Dairy Science. 77(1):253-258, 1994.

TITI, H. Effects of varying levels of protected fat on performance of Shami goats during early and mid lactation. Turkish Journal of Veterinary and Animal Sciences. 35(2):67-74, 2011.

TOMOTAKE, H. et al. Comparison between Holstein cow's milk and Japanese-Saanen goat's milk in fatty acid composition, lipid digestibility and protein profile. Bioscience Biotechnology and Biochemistry. 70(11):2771-2774, 2006.

VAN SOEST, P.J.; ROBERTSON, J. B.; LEWIS, B. A. Methods for dietary fiber, neutral detergent fiber, and nonstarch polysaccharides in relation to nutrition. Journal of Dairy Scienc. 74(10):35833597, 1991.

ZAMBOM, M.A. et al. Ingestão, digestibilidade das rações e produção de leite em cabras Saanen submetidas a diferentes relações volumoso:concentrado na ração. Revista Brasileira de Zootecnia. 34(6):2505-2514, 2005. 